\title{
Kinetics of Quality Changes of Pangasius Fillets at Stable and Dynamic Temperatures, Simulating Downstream Cold Chain Conditions
}

\author{
Nga Mai and Van Huynh \\ Department of Food Technology, Nha Trang University, Nha Trang, Vietnam \\ Correspondence should be addressed to Nga Mai; ngamtt@ntu.edu.vn
}

Received 4 May 2017; Revised 19 July 2017; Accepted 26 July 2017; Published 5 September 2017

Academic Editor: Maria Rosaria Corbo

Copyright (c) 2017 Nga Mai and Van Huynh. This is an open access article distributed under the Creative Commons Attribution License, which permits unrestricted use, distribution, and reproduction in any medium, provided the original work is properly cited.

\begin{abstract}
This study was about the quality changes of Pangasius fillets during storage under simulated temperature conditions of downstream cold chain. Sensory, chemical, and microbiological analyses were conducted over storage time and bacterial growth was modelled. Sensory quality index (QI), at five stable $\left(1,4,9,15\right.$, and $\left.19 \pm 1^{\circ} \mathrm{C}\right)$ and three dynamic temperatures, progressed faster at higher temperatures, especially with sooner temperature abuses. Total volatile basic nitrogen remained under the acceptable limit throughout all the storage conditions. Total viable psychrotrophic counts (TVC) were around $5.68 \pm 0.24 \log _{\mathrm{CFU} \mathrm{g}} \mathrm{g}^{-1}$ at the beginning and exceeded the limit of $6 \log \mathrm{CFU} \mathrm{g}^{-1}$ after 216, 96, 36, 16, and $7 \mathrm{~h}$ at 1, 4, 9, 15, and $19 \pm 1^{\circ} \mathrm{C}$, respectively. Meanwhile, Pseudomonas counts started at $3.81 \pm 0.53 \log \mathrm{CFU} \mathrm{g}{ }^{-1}$ and reached $4.60-6.36 \log \mathrm{CFU} \mathrm{g}^{-1}$ by the time of TVC rejection. Since lower shelf lives were given by TVC rather than QI, it should be appropriate to base the product shelf life on the TVC acceptable limit. Kinetics models based on the Baranyi and Roberts and square root models, developed for TVC and Pseudomonas spp., gave acceptable bacterial estimations at dynamic temperatures, with over $80 \%$ of observed counts within the acceptable simulation zone, revealing promising model applicability as a supporting tool for cold chain management. However, further improvement and validation of the models are needed.
\end{abstract}

\section{Introduction}

Temperature is among the most important factors affecting the quality of aquatic products $[1,2]$. At the end of a cold supply chain, aquatic products are normally subjected to chill-stored conditions with temperature fluctuations and/or abuses [3-5], which affect their quality and shorten their shelf life [2]. Continuous monitoring of the temperatures and assessing the sensory, chemical, and microbiological changes of aquatic products over time are useful tools for determining their quality, estimating shelf life, and supporting quality management $[2,6-8]$. Quality index (QI), a total sensory score obtained from the quality index method (QIM), and total volatile basic nitrogen (TVB-N), produced by enzymatic and microbiological activities, are commonly used as freshness indicators of fish $[6,7]$. Furthermore, TVB-N contents along with microbial counts are frequently used to endorse the rejection time estimated by QIM [9]. Total viable psychrotrophic counts (TVC) and specific spoilage organisms (SSOs) such as Pseudomonas spp. during cold storage of fish also serve as good indicators for fish freshness [10-12], since Pseudomonas spp. are a common SSO of iced fresh water fish [13]. Five species of Pseudomonas (P. otitidis, $P$. hibiscicola, $P$. geniculate, $P$. beteli, and $P$. aeruginosa) were found from Pangasius at filleting and trimming steps of a large-scale factory in Mekong Delta of Vietnam [14]. SSOs often cause sensory spoilage, with off-odors and off-flavors, when they reach concentrations above $7 \log \mathrm{CFU} \mathrm{g}^{-1}$ in fresh fish [15].

Kinetic modelling of microbial growth under simulated supply chain conditions is becoming more and more important for monitoring food contamination, shelf life, and risk assessment $[4,8,16]$. Several models considered appropriate for food systems, for example, Baranyi and Roberts model [17], Gompertz model [18], Ratkowsky equation [19], and the Arrhenius equation [20], have been parameterized for SSOs 
TABLE 1: Storage conditions of the three dynamic temperature regimes.

\begin{tabular}{lccccc}
\hline & Regime & Temperature & & Total storage time (h) \\
& & $1^{\circ} \mathrm{C}$ & $28-30^{\circ} \mathrm{C}$ & $9^{\circ} \mathrm{C}$ & 70 \\
$(1)$ & Dynamic 1 & $48 \mathrm{~h}$ & $2 \mathrm{~h}$ & $20 \mathrm{~h}$ & 47 \\
$(3)$ & Dynamic 2 & $27 \mathrm{~h}$ & $1 \mathrm{~min} / 30 \mathrm{~min}, 2 \mathrm{~h}^{*}$ & $18 \mathrm{~h}$ & 50 \\
\hline
\end{tabular}

${ }^{*}$ Abuses from $1^{\circ} \mathrm{C}$ to $28-30^{\circ} \mathrm{C}$ for 1 min every 30 min during storage hours $2-5$ and $9-12$ and for $2 \mathrm{~h}$ during storage hours $48-50 .{ }^{* *}$ Abuses from $1^{\circ} \mathrm{C}$ to $28-30^{\circ} \mathrm{C}$ for 5 min every $2 \mathrm{~h}$ during storage hours $0-12$ and $24-36$.

and/or pathogens in certain food/seafood products under isothermal and nonisothermal conditions. For example, they have been fitted for the growth of Pseudomonas psychrophila and Carnobacterium maltaromaticum in tropical shrimp (Penaeus notialis) [8], TVC and lactic acid bacteria (LAB) in vacuum packed chilled tuna [5], and pseudomonads in aerobically stored gilt-head sea bream [12].

Tra catfish (Pangasius hypophthalmus) is a popular commercial farmed aquatic species traded worldwide with large markets like the US, EU, Asia, and Latin America [21]. Vietnam remains the largest exporter of Pangasius with a value of 1.715 billion USD in 2016 [22]. Skinless and boneless frozen/chilled Pangasius fillets are one of the most common product types [23, 24]. Therefore, it is of outmost importance to clearly understand the kinetics of quality changes of this product under simulated supply chain condition to support decision-making in cold chain management. Several researches with this product type have been focused on its $\mathrm{pH}$ and sensory changes during storage at $0,3,5$, and $10^{\circ} \mathrm{C}[25]$, sensory QI changes at $0-2^{\circ} \mathrm{C}$ [26], microflora during processing [14], microbiological spoilage with vacuum and modified atmosphere packaging [27], import risk analysis of this product to New Zealand from Vietnam [28], composition and quality attributes of conventionally and organically farmed Pangasius fillets on the German market [23], and so on. However, sensory, chemical, and SSO quality changes of Pangasius fillets under stable and dynamic temperatures at downstream steps of the supply chain have not been systematically studied. To the best of our knowledge, no microbiological models have been developed for the product so far.

This work was to find out the quality changes of Pangasius fillets under simulated temperature conditions of cold chain downstream steps by assessing sensory, chemical, and microbiological changes and kinetic modelling of bacterial growth. This would enable the estimation of the product quality and shelf life based on temperature history to support cold chain management.

\section{Materials and Methods}

2.1. Preparation of Fish Samples. Farmed Tra catfish (Pangasius hypophthalmus) fillets of size 170/220 were used. Each stable temperature regime worked with 5 batches (batches $1-5)$, while every dynamic temperature regime did with 3 batches (batches 1-3); each consisted of 105-112 fillets.

Frozen fillets in semiblocks in plastic bags, fully covered with $500 \mathrm{~g}$ cooling mats in $30 \mathrm{~kg}$ insulated boxes, were transported by car from a factory, located in An Giang province of Vietnam, on the day of processing to the laboratories in Nha Trang city within 1 day. A 3M TL30 temperature logger (3M, Saint Paul, MN, USA) was put on top of the fish blocks to record the product temperature at $10 \mathrm{~min}$ intervals with a precision of $\pm 0.5^{\circ} \mathrm{C}$. At the laboratories, fish was stored in a freezer at $18 \pm 2^{\circ} \mathrm{C}$. Before each study, fillets were thawed overnight in a refrigerator at $1 \pm 1^{\circ} \mathrm{C}$, packed 1 fillet per polystyrene tray, and covered with thin polyethylene film. This was to simulate a real supply chain situation in Vietnam and elsewhere that frozen and/or fresh fish is commonly repacked into retail package at retailers $[2,24]$.

2.2. Storage Conditions. Fish trays were stored in a refrigerator with five stable temperature conditions of $1,4,9,15$, and $19 \pm 1^{\circ} \mathrm{C}$ and three dynamic temperature regimes, namely, Dynamic 1, Dynamic 2, and Dynamic 3 (Table 1), simulating downstream conditions of the supply chain. Starting point of the storage right after repack was considered as time $0(0 \mathrm{~h})$.

At Dynamic 1 , fish fillets were stored at $1 \pm 1^{\circ} \mathrm{C}$, assuming that they were kept in a retail refrigerator/cold store, for $48 \mathrm{~h}$ (2 days). Then they were placed outside at room temperature (of $28-30^{\circ} \mathrm{C}$ ) for $2 \mathrm{~h}$ to simulate that they were bought and carried home by an end customer/consumer. Finally, the product was stored at $9 \pm 1^{\circ} \mathrm{C}$, simulating a household refrigerator condition, until unfit for human consumption.

At Dynamic 2, fish fillets were first stored at $1 \pm 1^{\circ} \mathrm{C}$ at 7:00 AM of day 0; from $9 \mathrm{AM}$ to $12 \mathrm{AM}$ and from $4 \mathrm{PM}$ to 7 $\mathrm{PM}$ of day 0 , refrigerator door was opened for $1 \mathrm{~min}$ every $30 \mathrm{~min}$, simulating the product kept in a retail refrigerator at $1 \pm 1^{\circ} \mathrm{C}$ for $27 \mathrm{~h}$ with $1 \mathrm{~min}$ door opening every $30 \mathrm{~min}$ at busy shopping hours. Then the fish was placed outside at ambient temperature (of $28-30^{\circ} \mathrm{C}$ ) for $2 \mathrm{~h}$, assuming that the product was purchased at $10 \mathrm{AM}$ of day 1 (after $27 \mathrm{~h}$ of storage in retail refrigerator) and carried home. Finally, the product was stored at $9 \pm 1^{\circ} \mathrm{C}$, resembling a household refrigerator condition, until it is unfit for human consumption.

Dynamic 3 assumed that fish fillets were kept in a chilled store of a retailer at $1 \pm 1^{\circ} \mathrm{C}$, started from $8 \mathrm{AM}$ of day 0 until being unfit for human consumption. Every day, from $8 \mathrm{AM}$ to $8 \mathrm{PM}$, store door was opened for $5 \mathrm{~min}$ every $2 \mathrm{~h}$, simulating conditions of loading and unloading the product at the retailer store.

Samples were taken over storage time from each batch for quality assessment. Each sample included 2 fillets for QIM, 2 fillets for TVB-N, and another one for microbiological analyses. 
For continuous monitoring of the temperatures, DS1922L-F5 iButton ${ }^{\circledR}$ loggers (Maxim Integrated Products, Inc., CA) were put on some tray surface and tray bottom and inside the trays in direct contact with the fish recording temperature at $10 \mathrm{~min}$ intervals, while EC850A loggers (MicroLogPRO II, Israel) were used for refrigerator temperature monitoring.

2.3. Sensory Evaluation. Sensory evaluation of raw fillets was conducted by 3 panellists familiar with QIM, selected and trained in accordance with ISO 8586: 2012 [29]. The QIM scheme for chill-stored Pangasius fillets consisted of 6 attributes (skin side colour, backbone side mucus, backbone side colour, backbone side texture, backbone side odour, and backbone side stickiness) of 1-3 demerit scores with the total QI of 13 [26]. The QIM evaluation was carried out with 2 fillets from each batch per sampling point; each session worked with fish from 2 different batches. The fillets were coded with random 3-digit numbers, placed in a random order, and evaluated individually.

2.4. Chemical Analysis. Analysis of TVB-N was performed as described by Malle and Tao [30] in duplicate. Fish fillets were minced and extracted with a $7.5 \%$ aqueous trichloroacetic acid solution. TVB-N was steam distilled into boric acid solution and titrated with sulphuric acid solution.

2.5. Microbiological Analysis. Fillet was aseptically minced. Two to five replicate samples were evaluated for each storage regime. Minced flesh (25 g) was mixed with $225 \mathrm{~mL}$ of chilled saline peptone diluent in a stomacher for 1 minute. Successive 10 -fold dilutions were done as required. TVC was done on plate count agar (Merck, Germany). Enumeration of presumptive pseudomonads was performed using Pseudomonas Agar Base (Merck, Germany) with Cephaloridine Fucidin Cetrimide selective Agar Supplement (Merck, Germany) [31]. Spread-plating was used for all media. Plates were incubated at $19 \pm 1^{\circ} \mathrm{C}$ for 5 days. Counts are reported as decimal logarithmic average values of colony-forming units per gram $\left(\log \mathrm{CFU} \mathrm{g}^{-1}\right)$.

2.6. Microbiological Growth Modelling. Measured data of TVC and Pseudomonas spp. at five stable temperature conditions was fitted, using DMFIT available software on ComBase website (https://browser.combase.cc/DMFit.aspx), with the primary Baranyi and Roberts model $[17,32]$ as follows (see (1)):

$$
\begin{aligned}
& y=y_{\max } \\
&+\ln \left(\frac{1+\exp \left(\mu_{\max } t-h_{0}\right)-\exp \left(-h_{0}\right)}{\exp \left(y_{\max }-y_{0}\right)+\exp \left(\mu_{\max } t-h_{0}\right)-\exp \left(-h_{0}\right)}\right) \\
& h_{0}=\ln \left(\frac{1+q_{0}}{q_{0}}\right) \\
& \lambda \cdot \mu_{\max }=\ln \left(\frac{1+q_{0}}{q_{0}}\right)=h_{0}
\end{aligned}
$$

where $y$ is the decimal logarithm of bacterial counts at time $t\left(\log \mathrm{CFU} \mathrm{g}^{-1}\right) ; y_{0}$ is the decimal logarithm of initial bacterial counts $\left(\log \mathrm{CFU} \mathrm{g}^{-1}\right)$; $y_{\max }$ is the decimal logarithm of maximum bacterial counts $\left(\log \mathrm{CFUg}^{-1}\right) ; \mu_{\max }$ is the maximum specific growth rate $\left(\mathrm{h}^{-1}\right) ; \lambda$ is the lag time $(\mathrm{h}) ; q_{0}$ represents physiological state of the bacterial cells introduced; $h_{0}$ is considered as a statically stable transformation of $q_{0}$.

The dependency of bacterial growth on temperatures was modelled with the secondary square root model of Ratkowsky [19] as follows (see (2)):

$$
\sqrt{\mu_{\max }}=b\left(T-T_{\min }\right),
$$

where $T_{\min }$ is the conceptual minimum temperature for the bacterial growth $\left({ }^{\circ} \mathrm{C}\right)$; $T$ is the temperature $\left({ }^{\circ} \mathrm{C}\right) ; b$ is the regression coefficients $\left({ }^{\circ} \mathrm{C}^{-1} \mathrm{~h}^{-1 / 2}\right)$.

2.7. Validation of the Kinetics Models. The accuracy of the fittings was evaluated based on the coefficient of determination $\left(R^{2}\right)$ and standard error of fit (SE of fit) $[20,32]$.

For further validation of the developed kinetics models, data from three dynamic temperature regimes were used. The primary and secondary models were combined to predict the bacterial growth at dynamic temperature regimes within time-temperature history intervals of constant temperatures [20]. The acceptable simulation zone (ASZ), defined as $\pm 0.5 \log$ CFU g $^{-1}$ from the predicted counts, was used for comparison with bacterial observed growth; and the models would be considered acceptable if at least $70 \%$ of the observed counts was within the ASZ of prediction [33-36].

2.8. Data Analysis. Microsoft Excel 2010 (Microsoft, Redmond, WA, USA) was used to calculate means and standard deviations and to build graphs. One-way ANOVA (analysis of variance) and post hoc Tukey's test were conducted with the software SPSS version 17.0 (SPSS, Chicago, Il, USA) to compare the mean values for a statistical significant level of 0.05 .

\section{Results and Discussion}

3.1. Sensory Changes of Pangasius Fillets at Different Storage Conditions. At stable temperature conditions, QI of Pangasius fillets has increased over time at each storage temperature condition and with faster changes at higher temperatures, well observed from trendlines (Figure 1). The fact that QI is close to zero for very fresh products and went up as fish deteriorated is in good agreement with the QIM results of other fishery products stored at low temperatures $[6,10,37$, $38]$. At the end of the study period, QI reached mean scores of $10.4,6.9,7.2,6.2$, and 6.4 , accounting for $80 \%, 53 \%, 55 \%$, $47 \%$, and $49 \%$ of the total QI of the scheme after $360 \mathrm{~h}$ at $1 \pm 1^{\circ} \mathrm{C}, 168 \mathrm{~h}$ at $4 \pm 1^{\circ} \mathrm{C}, 72 \mathrm{~h}$ at $9 \pm 1^{\circ} \mathrm{C}, 26 \mathrm{~h}$ at $15 \pm 1^{\circ} \mathrm{C}$, and $12 \mathrm{~h}$ at $19 \pm 1^{\circ} \mathrm{C}$, respectively. According to Sykes at al. [39], the storage of aquatic products should be ended when QI value is around 75\% of the total QIM scale (i.e., when $\mathrm{QI}=75 \% * 13 \approx 9.8$ in this study), which indicates that the shelf life of Pangasius fillets was around $336 \mathrm{~h}$ (14 days) at $1 \pm 1^{\circ} \mathrm{C},>168 \mathrm{~h}$ at $4 \pm 1^{\circ} \mathrm{C},>72 \mathrm{~h}$ at $9 \pm 1^{\circ} \mathrm{C},>26 \mathrm{~h}$ at $15 \pm 1^{\circ} \mathrm{C}$, 


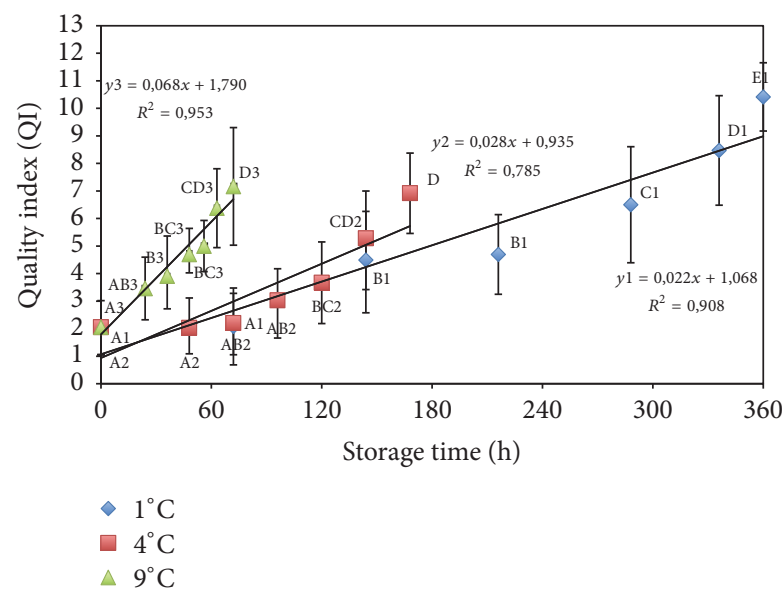

(a)

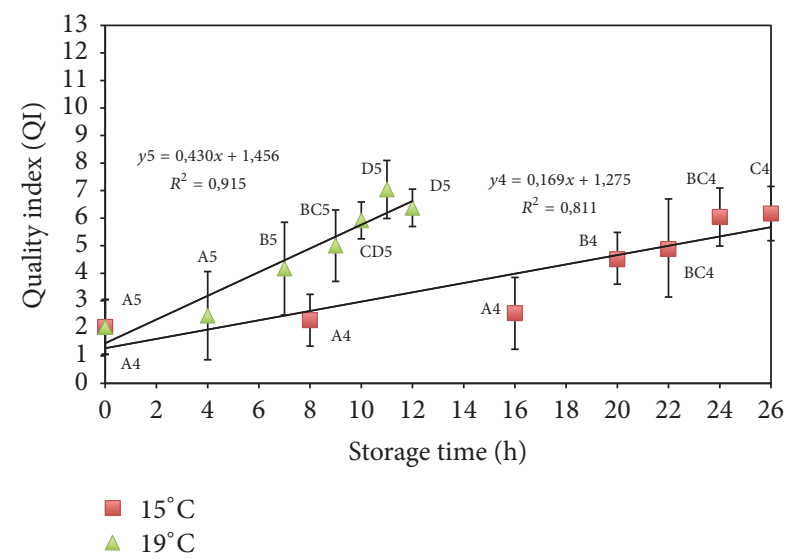

(b)

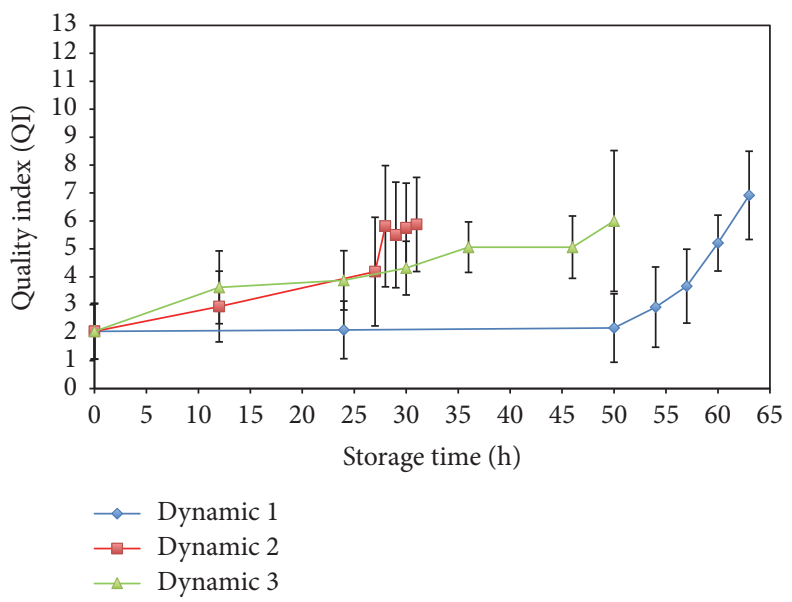

(c)

Figure 1: Changes in quality index (QI) of Pangasius fillets during storage at (a) 1,4 , and $9 \pm 1^{\circ} \mathrm{C}$, (b) 15 and $19 \pm 1^{\circ} \mathrm{C}$, and (c) dynamic temperature conditions. Different letters (A, B, C, D, and E) with numbers $(1,2,3,4$, and 5$)$ indicate significantly different QI mean values $(P<0.05)$ between samples over storage time of each temperature regime. In the regression equations, $y$ is $\mathrm{QI}$ and $x$ is storage time $(\mathrm{h})$.

and $>12 \mathrm{~h}$ at $19 \pm 1^{\circ} \mathrm{C}$. The QIM results at $1 \pm 1^{\circ} \mathrm{C}$ cofounded well with the findings from a previous study demonstrating that the maximal shelf life of Pangasius fillets stored at $0-2^{\circ} \mathrm{C}$ was 15 days as evaluated by QDA [26]. For skinless Pangasius fillets from Malaysia, Abbas et al. [25] predicted shelf lives of 16-18 days in ice storage at $0-2^{\circ} \mathrm{C}$. For skin-on Pangasius fillets stored in ice, Bao [40] found a shelf life of about 12 days. For whole Pangasius from Bangladesh stored in ice, Azam et al. [41] found shelf lives of medium size (550-650 g) fish around 12 days in summer season and 10 days in winter season based on sensory evaluation. The difference in shelf life of Pangasius products might be due to the variation in product types (skinless versus skin-on fillets, as well as whole fish), fish origin (Vietnam versus Malaysia, as well as Bangladesh), storage conditions (chilled air versus in ice), and so on.

At all five stable temperatures, QI was well linearly correlated with storage time, which agreed well with other studies about the linear correlation of QI and storage time $[6,38-40]$. The presented regression equations (Figures 1(a) and 1(b)) are good tools for freshness evaluation and shelf life estimation of the product.
At dynamic temperature conditions, an increasing trend of QI over time was also observed (Figure 1(c)). When comparing the changes of Pangasius fillet QI at stable 1 $\pm 1^{\circ} \mathrm{C}$ (Figure 1(a)) and those at dynamic $1^{\circ} \mathrm{C}$ (Dynamic 3 , Figure 1(c)), it could be seen that QI in the latter case evolved faster than the first one. This difference could be explained by the fact that temperature abuse in the latter case caused faster rate of spoilage $[2,20]$. Comparing QI from the dynamic regimes 1 and 2 (Figure 1(c)), it was found that the sooner temperature abuse occurred (after $48 \mathrm{~h}$ of Dynamic 1 and after $27 \mathrm{~h}$ of Dynamic 2), the faster QI changed, clearly observed after the temperature shifting. The results from dynamic conditions of storage show that QIM has potential for detecting the sensory changes in temperature fluctuation/abuse situations.

3.2. TVB-N Changes of Pangasius Fillets at Different Storage Conditions. At all studied temperature storage regimes, including five stable and three dynamic temperature conditions, TVB-N contents in fish fillets were initially as low as $4.41 \mathrm{mg} \mathrm{N} / 100 \mathrm{~g}$ and remained well below the acceptable 


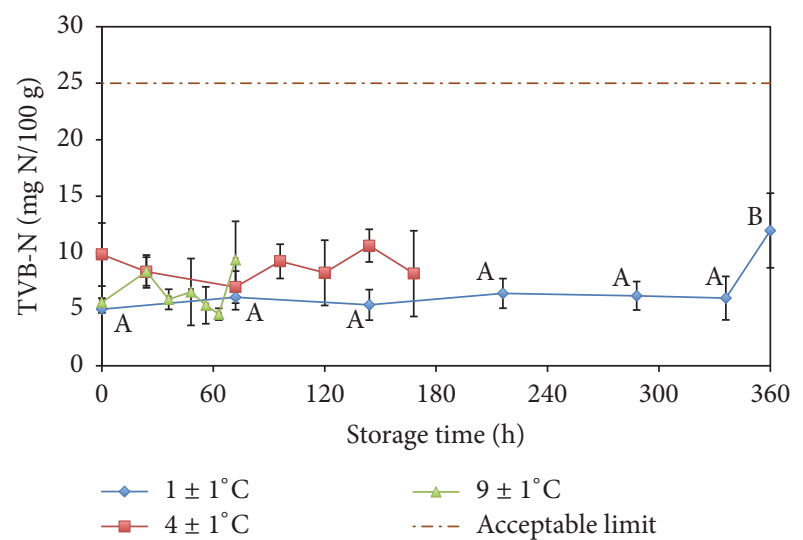

(a)

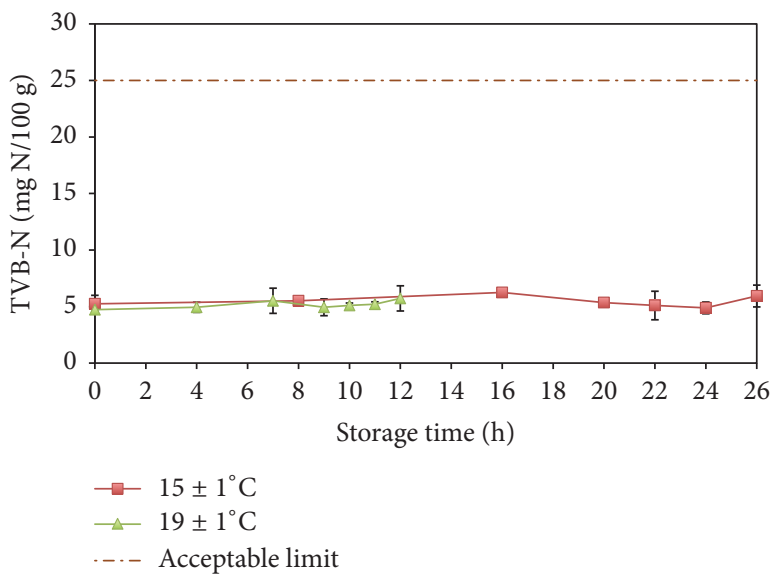

(b)

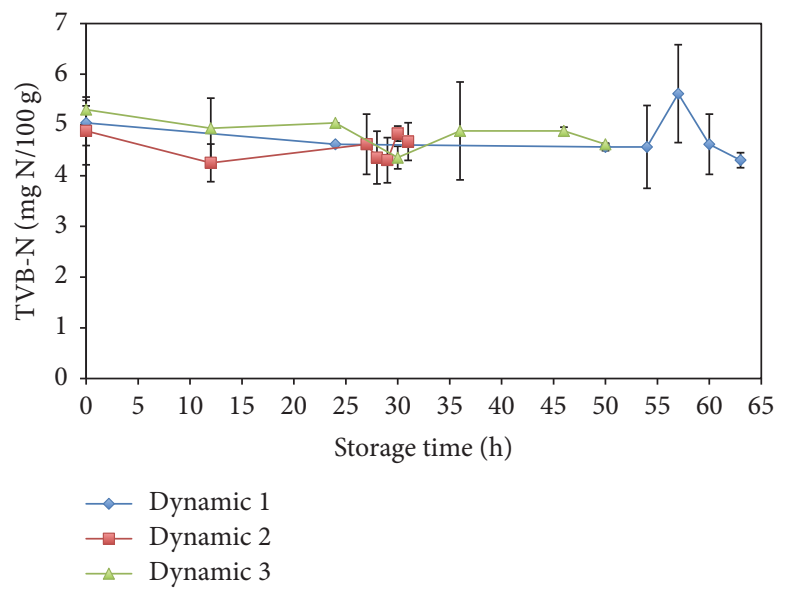

(c)

Figure 2: Changes in TVB-N of Pangasius fillets during storage at (a) 1,4 , and $9 \pm 1^{\circ} \mathrm{C}$, (b) 15 and $19 \pm 1^{\circ} \mathrm{C}$, and (c) dynamic temperature conditions.

limit for Pangasius fillet of $25 \mathrm{mg} \mathrm{N} / 100 \mathrm{~g}$ [42] throughout storage time (Figure 2). No significant changes $(P>0.05)$ were observed in TVB-N level during storage periods at 4, 9, 15 , and $19 \pm 1^{\circ} \mathrm{C}$ and at three dynamic temperature regimes. At $1 \pm 1^{\circ} \mathrm{C}$, TVB-N remained around $4.31-8.09 \mathrm{mg} \mathrm{N} / 100 \mathrm{~g}$ until the end of the storage $(360 \mathrm{~h})$, where its contents significantly rose $(P<0.05)$ up to $11.97 \pm 3.30 \mathrm{mg} \mathrm{N} / 100 \mathrm{~g}$. This agreed well with previous studies demonstrating that TVB-N level only increases at the later time of storage when spoilage becomes evident $[2,43]$. Ammonia contents in skinon Pangasius fillets stored in ice were $4.5 \mathrm{mg} \mathrm{N} / 100 \mathrm{~g}$ at initial time and $49 \mathrm{mg} \mathrm{N} / 100 \mathrm{~g}$ at day 14 [40]. Meantime, for whole Pangasius of medium size, the initial content of TVB-N was $4.05 \pm 0.25 \mathrm{mg} \mathrm{N} / 100 \mathrm{~g}$, and it exceeded the level of $30 \mathrm{mg} \mathrm{N} / 100 \mathrm{~g}$ after 14 days in ice [41]. In a study on cod loin air stored at $0.5 \pm 0.5^{\circ} \mathrm{C}$, TVB-N remained low during the first 10 days of storage, after which its level increased rapidly, exceeding the human consumption allowed limit for gadoids of $35 \mathrm{mg} \mathrm{N} / 100 \mathrm{~g}$ [44] after 13 days [2]. To summarize, TVB$\mathrm{N}$ contents in Pangasius fillets in the current study were still within the limit for human consumption at the end of the storage periods of different temperature conditions, which reveals that TVB-N could not be a useful indicator for shelf life determination of this product.

3.3. Kinetics of TVC and Pseudomonas Growth in Pangasius Fillets at Stable Temperature Conditions. At stable temperatures, the TVC was around $5.68 \pm 0.24 \log \mathrm{CFU} \mathrm{g}^{-1}$ at the beginning and increased over time more rapidly at higher storage temperatures, exceeding the acceptable limit of $6 \log \mathrm{CFU} \mathrm{g}^{-1}$ [42] after 216, 96, 36, 16, and $7 \mathrm{~h}$ at $1,4,9,15$, and $19 \pm 1^{\circ} \mathrm{C}$, respectively (Figure 3(a)). Meanwhile, Pseudomonas counts started at $3.81 \pm 0.53 \log \mathrm{CFU} \mathrm{g}^{-1}$ and grew with the similar trend, reaching $4.60-6.36 \log _{\mathrm{CFU} \mathrm{g}}{ }^{-1}$ by the time of TVC rejection (Figure 3(b)). These levels of Pseudomonas spp. were much lower than the level of $7 \log \mathrm{CFU} \mathrm{g}^{-1}$, which caused spoilage for fresh gilt-head sea bream Mediterranean fish (Sparus aurata) [15], or the set level of $7.5 \log \mathrm{CFU} \mathrm{g}^{-1}$ for the shelf life of fresh pork or poultry [20].

When comparing the shelf life limits of the studied product based on QI and TVC, it can be seen that TVC gave much lower shelf lives than sensory QI did. In contrast, some other studies found that sensory rejection time was well associated with a TVC level of $6 \log \mathrm{CFU} \mathrm{g}^{-1}$, for example, for 
TABLE 2: Estimated parameters with standard error (SD) of the square root model for TVC and Pseudomonas growth in Pangasius fillets stored at low temperatures.

\begin{tabular}{lcccrrr}
\hline Microorganisms & $b\left({ }^{\circ} \mathrm{C}^{-1} \mathrm{~h}^{-1 / 2}\right)$ & $\mathrm{SD}$ of $b\left({ }^{\circ} \mathrm{C}^{-1} \mathrm{~h}^{-1 / 2}\right)$ & $T_{\min }\left({ }^{\circ} \mathrm{C}\right)$ & $\mathrm{SD}$ of $T_{\min }\left({ }^{\circ} \mathrm{C}\right)$ & $R^{2}$ & $\mathrm{SE}$ of fit \\
\hline TVC & 0.011059 & 0.00131 & -10.87829 & 1.38524 & 0.84577 & 0.033892 \\
Pseudomonas spp. & 0.144475 & 0.01293 & -13.36799 & 1.19593 & 0.88034 & 0.028596 \\
\hline
\end{tabular}

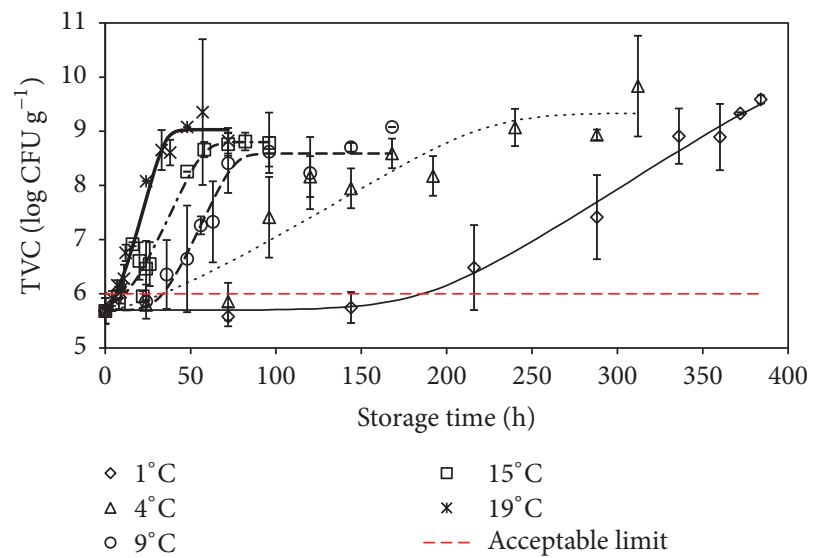

(a)

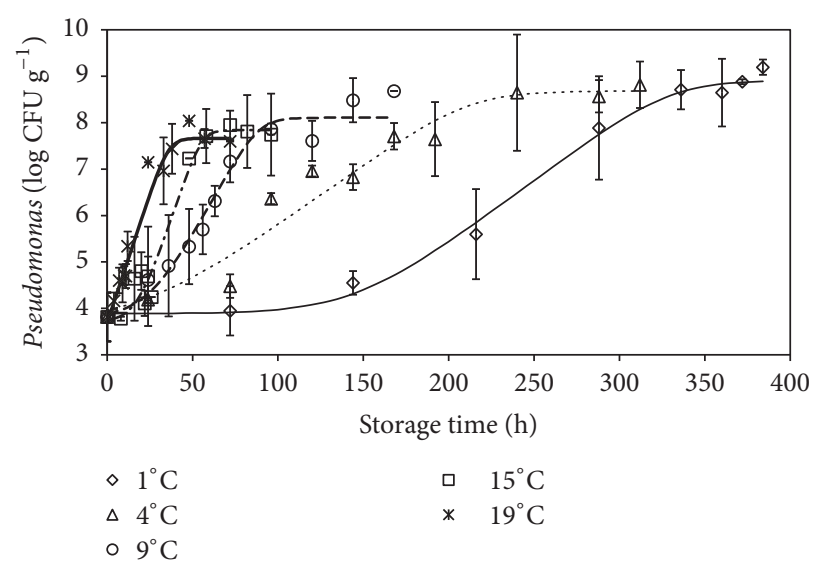

(b)

FIgure 3: Changes in (a) TVC and (b) Pseudomonas counts of Pangasius fillets during storage at stable temperatures, with observed values (markers) and fitting curves (lines) using primary Baranyi and Roberts model.

wild turbot [45] or for farmed turbot stored in flake ice [46]. Meanwhile, it was reviewed that there have been no common rules on the bacterial counts and the sensory rejection time [4]; for example, the bacterial level at the sensory shelf life limit was ca. $7 \log \mathrm{CFU} \mathrm{g}^{-1}$ [12] or ca. $8 \log \mathrm{CFU} \mathrm{g}^{-1}[47,48]$. Findings of this study indicate that the shelf life of Pangasius fillets at low temperatures would rather be based on the limit level of TVC $\left(6 \log \mathrm{CFU} \mathrm{g}^{-1}\right)$ than on the sensory QI (75\% of the total scale).

To observe propagation trends of TVC and Pseudomonas spp. over time at stable temperatures, Baranyi and Roberts model was used to fit the microbial data, and the results were shown with fitted curves in Figure 3. The maximum growth rate, generally, increased with storage temperatures, clearly observed for TVC and Pseudomonas counts at temperatures of $1,9,15$ and $19^{\circ} \mathrm{C}$, which agreed well with the growth rate increasing trend with temperatures from other studies, for example, for total bacteria and Pseudomonas in turbot (Psetta maxima) at $0,5,10$, and $15^{\circ} \mathrm{C}$ [4] or for Pseudomonas counts in poultry at temperatures of $2,4,10,15$, and $20^{\circ} \mathrm{C}$ [32]. Furthermore, the growth of psychrotrophic bacteria was shown to have very short lag phase (estimated about $6.313 \pm 4.561 \mathrm{~h}$ for TVC) or no lag (for Pseudomonas spp.) at $19 \pm 1^{\circ} \mathrm{C}$ (Figure 3), which can be explained by the fact that the indicated temperature is close to the optimum range for their growth [49]. The maximum bacterial counts at stationary phase were found to converge to about $9.20 \log \mathrm{CFU} \mathrm{g}^{-1}$ for TVC and $8.24 \log \mathrm{CFU} \mathrm{g}^{-1}$ for Pseudomonas spp. (Figure 3), which agreed well with the findings for other fish products; for example, maximum bacterial concentrations of total bacteria and Pseudomonas in turbot (Psetta maxima) at isothermal range of $0-15^{\circ} \mathrm{C}$ were $7.55-10.20$ and $7.05-9.07 \log \mathrm{CFU} \mathrm{g}^{-1}$, respectively [4].

3.4. Modelling the Influence of Temperature on the Growth of TVC and Pseudomonas spp. To exploit the influence of temperatures on the growth of the bacteria, the square root model [19] was used as secondary model and fit parameters were shown in Table 2. The parameters were $T_{\min }=-10.87829 \pm$ $1.38524^{\circ} \mathrm{C}$ and $b=0.011059 \pm 0.00131\left({ }^{\circ} \mathrm{C}^{-1} \mathrm{~h}^{-1 / 2}\right)$ for TVC and $T_{\min }=-13.36799 \pm 1.19593^{\circ} \mathrm{C}$ and $b=0.144475 \pm$ $0.01293\left({ }^{\circ} \mathrm{C}^{-1} \mathrm{~h}^{-1 / 2}\right)$ for Pseudomonas spp. The results were very similar to those of other seafood; for example, for the growth of Pseudomonas spp. in tropical shrimp (Penaeus notialis) stored at 0 to $28^{\circ} \mathrm{C}$, the model parameters were $T_{\min }$ $=-12.1^{\circ} \mathrm{C}$ with $95 \%$ confidence interval $(\mathrm{CI})\left(-13.1,-10.9^{\circ} \mathrm{C}\right)$ and $b=0.019$ with $95 \%$ CI $(0.017,0.021)$ [8]. Meanwhile, estimated parameters of the square root approach in the Baranyi and Roberts model for Pseudomonas in poultry within a temperature range of $2-20^{\circ} \mathrm{C}$ were $T_{\min }=-5.8812$ $\pm 2.466^{\circ} \mathrm{C}$ and $b=0.02045 \pm 0.0029\left({ }^{\circ} \mathrm{C}^{-1} \mathrm{~h}^{-1 / 2}\right)$ [32], which are somewhat different from those of aquatic products.

The coefficient of determination $\left(R^{2}\right)$ was relatively high (0.85 for TVC and 0.88 for Pseudomonas spp.) (Table 2), which indicates the possibility to further apply the models in estimation of the bacterial counts at dynamic temperature conditions.

\subsection{Validation of the Kinetics Models in Dynamic Temperature} Conditions. Data from the three dynamic regimes were used for validation of the model applicability, and results were shown in Figure 4. For dynamic temperature regime 1 


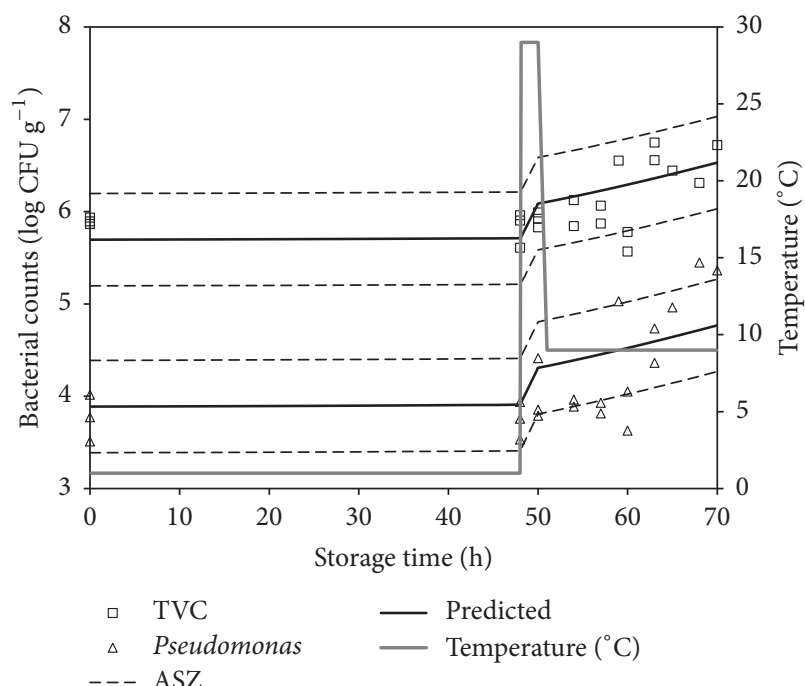

(a)

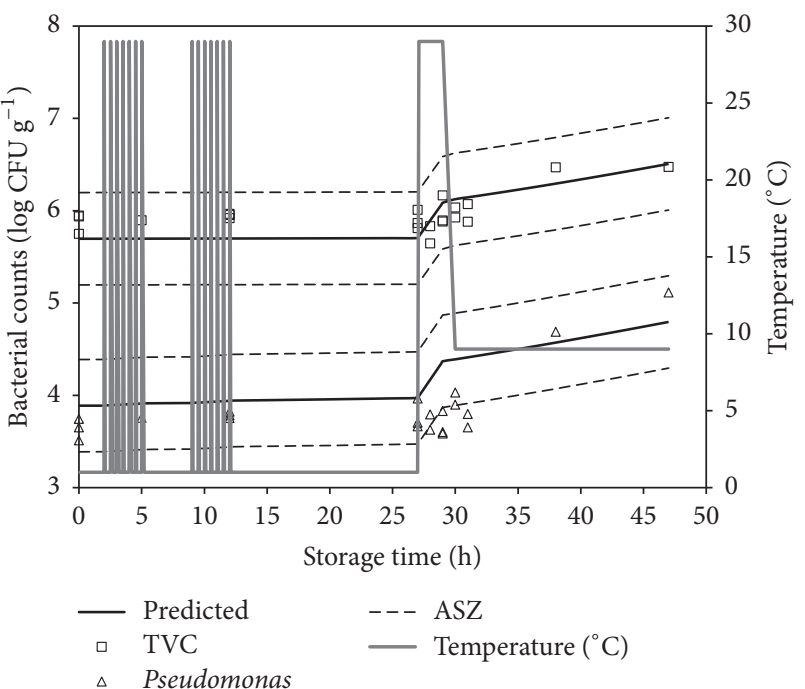

(b)

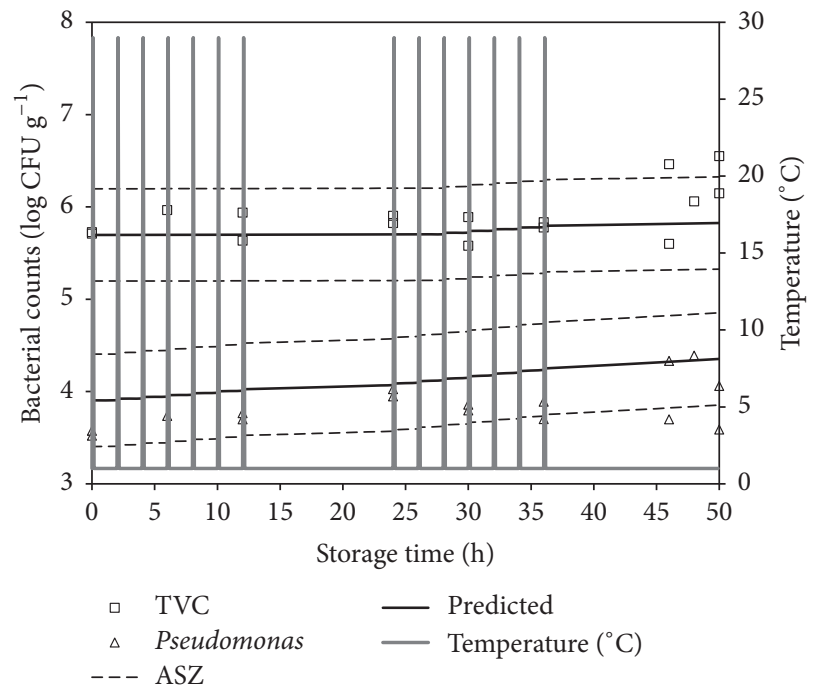

(c)

Figure 4: Observed and predicted growth of TVC and Pseudomonas spp. in Pangasius fillets during storage at dynamic temperature regimes: (a) Dynamic 1, (b) Dynamic 2, and (c) Dynamic 3.

(Dynamic 1, Figure 4(a)), most of the measured TVC (20 out of 21 observations, or $95.24 \%$ ) fell within the ASZ, and the left one $(1 / 21$, or $4.76 \%)$ was overestimated, which could be considered as a "fail-safe" prediction. For Pseudomonas counts, $18 / 21$ (85.71\%) measured counts lied within the ASZ, 2/21 were overestimated (9.52\% "fail-safe" prediction), and 1/21 (4.76\%) was underestimated, which could be considered as a "faildangerous" prediction. Similarly, for dynamic temperature regime 2 (Dynamic 2, Figure 4(b)), 100\% of observed TVC and $80.95 \%$ of observed Pseudomonas counts fell within the ASZ; and 19.05\% Pseudomonas counts were overestimated. Comparably, at dynamic temperature regime 3 (Dynamic 3, Figure 4(c)), $87.50 \%$ of observed TVC and Pseudomonas counts were within the ASZ of prediction, and the other $12.5 \%$ of TVC was underestimated and $12.5 \%$ of Pseudomonas spp. were overestimated.
The findings are comparable with those of other studies; for example, on average, about $83 \%$ of Listeria monocytogenes and $75 \%$ of LAB observed in cottage cheese were within the ASZ [35]; and 78\% of measured psychrotolerant pseudomonads in milk and cottage cheese lied in the ASZ [33].

The above results indicate that the developed kinetics models were acceptable for further application in prediction of TVC and Pseudomonas growth in Pangasius fillets at low temperatures, since more than $70 \%$ of the observed counts were within the ASZ [33-36].

In this study, due to short duration of storage, at the end, the TVC and Pseudomonas spp. have not reached the stationary phase yet. Therefore, further investigation with longer time of storage is needed in order to better validate the applicability of the models. In addition, to improve the models, more studies at other stable storage temperatures and 
more replications would be desired. Moreover, it is important to bear in mind that continuous improvement and validation of kinetics models used as a quality/shelf life prediction tool are essential in quality management [20].

\section{Conclusions}

Pangasius fillet QI showed a linear correlation with storage time at $1,4,9,15$, and $19 \pm 1^{\circ} \mathrm{C}$ with speedier QI raise at higher temperatures. Furthermore, QI changed faster if there were temperature abuses and if abuses occurred sooner. The findings revealed that QIM is capable of detecting sensory changes in temperature fluctuation/abuse situations. Meanwhile, TVB-N contents in fish fillets remained under the acceptable limit for human consumption till the end of all the storage conditions, which indicates that TVB-N could not be a useful indicator for shelf life determination of this product.

The TVC of Pangasius fillets exceeded the acceptable level of TVC $\left(6 \log \mathrm{CFU} \mathrm{g}^{-1}\right)$ in less than $216 \mathrm{~h}$ at $1 \pm 1^{\circ} \mathrm{C}, 96 \mathrm{~h}$ at 4 $\pm 1^{\circ} \mathrm{C}, 36 \mathrm{~h}$ at $9 \pm 1^{\circ} \mathrm{C}, 16 \mathrm{~h}$ at $15 \pm 1^{\circ} \mathrm{C}$, and $7 \mathrm{~h}$ at $19 \pm 1^{\circ} \mathrm{C}$, showing much lower shelf lives compared to those given by sensory QI. This reveals that the shelf life of Pangasius fillets stored at low temperatures should be based on the acceptable level of TVC.

Most observed bacterial counts $(\geq 87.50 \%$ of TVC and $80.95 \%$ of Pseudomonas spp.) at dynamic temperature regimes fell within the ASZ of the developed kinetics models, revealing the applicability of the model as a decision supporting tool in quality management. However, further improvement and validation of the models are needed.

\section{Conflicts of Interest}

The authors declare that there are no conflicts of interest regarding the publication of this paper.

\section{Acknowledgments}

This work was funded by the Ministry of Science and Technology of Vietnam under the Chinese-Vietnamese Bilateral Project "Research Collaboration, Development of Monitoring System Using Wireless Sensor Network for Quality Control and Energy Saving in Aquatic Product Cold Chain" (Contract no. 08/2014/HĐ-NĐT). Staffs from the Faculty of Food Technology, Nha Trang University, are thanked for their participation in the sensory evaluation.

\section{References}

[1] T. P. Labuza and B. Fu, "Use of time/temperature integrators, predictive microbiology, and related technologies for assessing the extent and impact of temperature abuse on meat and poultry products," Journal of Food Safety, vol. 15, no. 3, pp. 201-227, 1995.

[2] N. T. T. Mai, M. Gudjónsdóttir, H. L. Lauzon et al., "Continuous quality and shelf life monitoring of retail-packed fresh cod loins in comparison with conventional methods," Food Control, vol. 22, no. 6, pp. 1000-1007, 2011.
[3] N. T. T. Mai, B. Margeirsson, S. Margeirsson, S. G. Bogason, S. Sigurgísladóttir, and S. Arason, "Temperature mapping of fresh fish supply chains-air and sea transport," Journal of Food Process Engineering, vol. 35, no. 4, pp. 622-656, 2012.

[4] M. Nuin, B. Alfaro, Z. Cruz et al., "Modelling spoilage of fresh turbot and evaluation of a time-temperature integrator (TTI) label under fluctuating temperature," International Journal of Food Microbiology, vol. 127, no. 3, pp. 193-199, 2008.

[5] T. Tsironi, E. Gogou, E. Velliou, and P. S. Taoukis, "Application and validation of the TTI based chill chain management system SMAS (Safety Monitoring and Assurance System) on shelf life optimization of vacuum packed chilled tuna," International Journal of Food Microbiology, vol. 128, no. 1, pp. 108-115, 2008.

[6] O. O. Cyprian, K. Sveinsdóttir, H. Magnússon, and E. Martinsdóttir, "Application of quality index method (QIM) scheme and effects of short-time temperature abuse in shelf life study of fresh water arctic char (Salvelinus alpinus)," Journal of Aquatic Food Product Technology, vol. 17, no. 3, pp. 303-321, 2008.

[7] G. Olafsdottir, E. Martinsdóttir, J. Oehlenschläger et al., "Methods to evaluate fish freshness in research and industry," Trends in Food Science \& Technology, vol. 8, no. 8, pp. 258-265, 1997.

[8] D. S. Dabadé, P. Azokpota, M. J. R. Nout, D. J. Hounhouigan, M. H. Zwietering, and H. M. W. Den Besten, "Prediction of spoilage of tropical shrimp (Penaeus notialis) under dynamic temperature regimes," International Journal of Food Microbiology, vol. 210, pp. 121-130, 2015.

[9] A. P. B. dos Santos, M. M. Kushida, E. M. M. Viegas, and J. LapaGuimarães, "Development of Quality Index Method (QIM) scheme for Acoupa weakfish (Cynoscion acoupa)," LWT - Food Science and Technology, vol. 57, no. 1, pp. 267-275, 2014.

[10] A. C. Bonilla, K. Sveinsdottir, and E. Martinsdottir, "Development of Quality Index Method (QIM) scheme for fresh cod (Gadus morhua) fillets and application in shelf life study," Food Control, vol. 18, no. 4, pp. 352-358, 2007.

[11] L. Gram and H. H. Huss, "Microbiological spoilage of fish and fish products," International Journal of Food Microbiology, vol. 33, no. 1, pp. 121-137, 1996.

[12] K. Koutsoumanis, "Predictive modeling of the shelf life of fish under nonisothermal conditions," Applied and Environmental Microbiology, vol. 67, no. 4, pp. 1821-1829, 2001.

[13] L. Gram and P. Dalgaard, "Fish spoilage bacteria-problems and solutions," Current Opinion in Biotechnology, vol. 13, no. 3, pp. 262-266, 2002.

[14] A. N. Tong Thi, B. Noseda, S. Samapundo et al., "Microbial ecology of Vietnamese Tra fish (Pangasius hypophthalmus) fillets during processing," International Journal of Food Microbiology, vol. 167, no. 2, pp. 144-152, 2013.

[15] P. Tryfinopoulou, E. Tsakalidou, and G.-J. E. Nychas, "Characterization of Pseudomonas spp. associated with spoilage of gilthead sea bream stored under various conditions," Applied and Environmental Microbiology, vol. 68, no. 1, pp. 65-72, 2002.

[16] P. Dalgaard, "Modelling of microbial activity and prediction of shelf life for packed fresh fish," International Journal of Food Microbiology, vol. 26, no. 3, pp. 305-317, 1995.

[17] J. Baranyi and T. A. Roberts, "A dynamic approach to predicting bacterial growth in food," International Journal of Food Microbiology, vol. 23, no. 3-4, pp. 277-294, 1994.

[18] M. H. Zwietering, I. Jongenburger, F. M. Rombouts, and K. Van't Riet, "Modeling of the bacterial growth curve," Applied and Environmental Microbiology, vol. 56, no. 6, pp. 1875-1881, 1990.

[19] D. A. Ratkowsky, J. Olley, T. A. McMeekin, and A. Ball, "Relationship between temperature and growth rate of bacterial cultures," Journal of Bacteriology, vol. 149, no. 1, pp. 1-5, 1982. 
[20] S. Bruckner, A. Albrecht, B. Petersen, and J. Kreyenschmidt, "A predictive shelf life model as a tool for the improvement of quality management in pork and poultry chains," Food Control, vol. 29, no. 2, pp. 451-460, 2013.

[21] GLOBEFISH, "Good pangasius demand amidst tight supplies," in GLOBEFISH - Analysis and information on world fish trade, FAO, 2016.

[22] VASEP, Fisheries Trade Bulletin, Vietnam Association of Seafood Exporters and Producers, Hanoi, Vietnam, 2017.

[23] H. Karl, I. Lehmann, H. Rehbein, and R. Schubring, "Composition and quality attributes of conventionally and organically farmed Pangasius fillets (Pangasius hypophthalmus) on the German market," International Journal of Food Science and Technology, vol. 45, no. 1, pp. 56-66, 2010.

[24] E. Orban, T. Nevigato, G. D. Lena et al., "New trends in the seafood market. Sutchi catfish (Pangasius hypophthalmus) fillets from Vietnam: Nutritional quality and safety aspects," Food Chemistry, vol. 110, no. 2, pp. 383-389, 2008.

[25] K. A. Abbas, S. M. Sapuan, and A. S. Mokhtar, "Shelf life assessment of Malaysian Pangasius sutchi during cold storage," pp. 635-643.

[26] J. J. Rosales Jr. and F. Sulaiman, "Development of a quality index scheme for sensory evaluation of chill-stored pangasius hypophthalmus fillets," in Proceedings of the Conference on Food Science and Nutrition 2012 (ICFSN 2012). Traditional resources: scientific approaches towards quality foods, vol. 2, pp. 214227, School of Food Science and Nutrition Universiti Malaysia Sabah, Kota Kinabalu, Sabah, Malaysia, 2012.

[27] B. Noseda, M. T. Islam, M. Eriksson et al., "Microbiological spoilage of vacuum and modified atmosphere packaged Vietnamese Pangasius hypophthalmus fillets," Food Microbiology, vol. 30, no. 2, pp. 408-419, 2012.

[28] MAF, Import Risk Analysis: Frozen, Skinless And Boneless Fillet Meat of Pangasius Spp. Fish from Vietnam for Human Consumption, Ministry of Agriculture and Forestry, Wellington, New Zealand, 2008.

[29] ISO, ISO 8586:2012. SensorY Analysis - General Guidelines for The Selection, Training And Monitoring of Selected Assessors and Expert Sensory Assessors, The International Organization for Standardization, Geneva, Switzerland, 2012.

[30] P. Malle and S. H. Tao, "Rapid quantitative determination of trimethylamine using steam distillation," Journal of Food Protection, vol. 50, no. 9, pp. 756-760, 1987.

[31] L. H. Stanbridge and R. G. Board, "A modification of the Pseudomonas selective medium, CFC, that allows differentiation between meat pseudomonads and Enterobacteriaceae," Letters in Applied Microbiology, vol. 18, no. 6, pp. 327-328, 1994.

[32] R. Gospavic, J. Kreyenschmidt, S. Bruckner, V. Popov, and N. Haque, "Mathematical modelling for predicting the growth of Pseudomonas spp. in poultry under variable temperature conditions," International Journal of Food Microbiology, vol. 127, no. 3, pp. 290-297, 2008.

[33] V. Martinez-Rios, N. B. Østergaard, E. Gkogka, P. S. Rosshaug, and P. Dalgaard, "Modelling and predicting growth of psychrotolerant pseudomonads in milk and cottage cheese," International Journal of Food Microbiology, vol. 216, pp. 110-120, 2016.

[34] C. O. A. Møller, Y. Ilg, S. Aabo, B. B. Christensen, P. Dalgaard, and T. B. Hansen, "Effect of natural microbiota on growth of Salmonella spp. in fresh pork - A predictive microbiology approach," Food Microbiology, vol. 34, no. 2, pp. 284-295, 2013.

[35] N. B. Østergaard, A. Eklöw, and P. Dalgaard, "Modelling the effect of lactic acid bacteria from starter- and aroma culture on growth of Listeria monocytogenes in cottage cheese," International Journal of Food Microbiology, vol. 188, pp. 15-25, 2014.

[36] T. P. Oscar, "Validation of lag time and growth rate models for Salmonella Typhimurium: Acceptable prediction zone method," Journal of Food Science, vol. 70, no. 2, pp. M129-M137, 2005.

[37] E. Martinsd, K. Sveinsd, J. Luten et al., Sensory Evaluation of Fish Freshness: QIM Eurofish, 2001.

[38] K. Sveinsdottir, G. Hyldig, E. Martinsdottir, B. Jørgensen, and K. Kristbergsson, "Quality Index Method (QIM) scheme developed for farmed Atlantic salmon (Salmo salar)," Food Quality and Preference, vol. 14, no. 3, pp. 237-245, 2003.

[39] A. V. Sykes, A. R. Oliveira, P. M. Domingues, C. M. Cardoso, J. P. Andrade, and M. L. Nunes, "Assessment of European cuttlefish (Sepia officinalis, L.) nutritional value and freshness under ice storage using a developed Quality Index Method (QIM) and biochemical methods," LWT - Food Science and Technology, vol. 42, no. 1, pp. 424-432, 2009.

[40] H. N. D. Bao, "QIM Method Scores Quality, Shelf Life of PangasiusFillets," Global Aquaculture Advocate, pp. 28-30, 2006.

[41] K. Azam, S. Pervin, S. S. Naher et al., "Quality Changes in Pangus (Pangasius hypothamus) in relation to size and season during storage in ice," Pakistan Journal of Biological Sciences, vol. 8, no. 4, pp. 636-640, 2005.

[42] MARD, “TCVN 8338:2010: Frozen Tra fish (Pangasius hypophthalmus) fillet," in Department of Processing and Trade for Agro-forestry-Fisheries Products and Salt Production, Ministry of Agriculture and Rural Development (MARD), pp. 1-5, 2010.

[43] J. Oehlenschläger, "Suitability of ammonia-N, dimethylamine$\mathrm{N}$, trimethylamine- $\mathrm{N}$, trimethylamine oxide- $\mathrm{N}$ and total volatile basic nitrogen as freshness indicators in seafoods," in Methods to Determine The Freshness of Fish in Research And Industry, G. Olafsdottir et al., Ed., pp. 92-98, Intl. Inst. of Refrigeration, Paris, France, 1998.

[44] EU, “95/149/EC: Commission Decision of 8 March 1995 fixing the total volatile basic nitrogren (TVB-N) limit values for certain categories of fishery products and specifying the analysis method to be used," in L097, 29/04/1995. 95/149/EEC, pp. 84-87, 1995.

[45] Y. Ozogul, F. Ozogul, E. Kuley, A. S. Özkutuk, C. Gökbulut, and S. Köse, "Biochemical, sensory and microbiological attributes of wild turbot (Scophthalmus maximus), from the Black Sea, during chilled storage," Food Chemistry, vol. 99, no. 4, pp. 752758, 2006.

[46] Ó. Rodríguez, J. Barros-Velázquez, C. Piñeiro, J. M. Gallardo, and S. P. Aubourg, "Effects of storage in slurry ice on the microbial, chemical and sensory quality and on the shelf life of farmed turbot (Psetta maxima)," Food Chemistry, vol. 95, no. 2, pp. $270-278,2006$.

[47] P. Dalgaard, O. Mejlholm, and H. H. Huss, "Application of an iterative approach for development of a microbial model predicting the shelf-life of packed fish," International Journal of Food Microbiology, vol. 38, no. 2-3, pp. 169-179, 1997.

[48] E. K. Paleologos, I. N. Savvaidis, and M. G. Kontominas, "Biogenic amines formation and its relation to microbiological and sensory attributes in ice-stored whole, gutted and filleted Mediterranean Sea bass (Dicentrarchus labrax)," Food Microbiology, vol. 21, no. 5, pp. 549-557, 2004.

[49] D. A. Ratkowsky, R. K. Lowry, T. A. McMeekin, A. N. Stokes, and R. E. Chandler, "Model for bacterial culture growth rate throughout the entire biokinetic temperature range," Journal of Bacteriology, vol. 154, no. 3, pp. 1222-1226, 1983. 

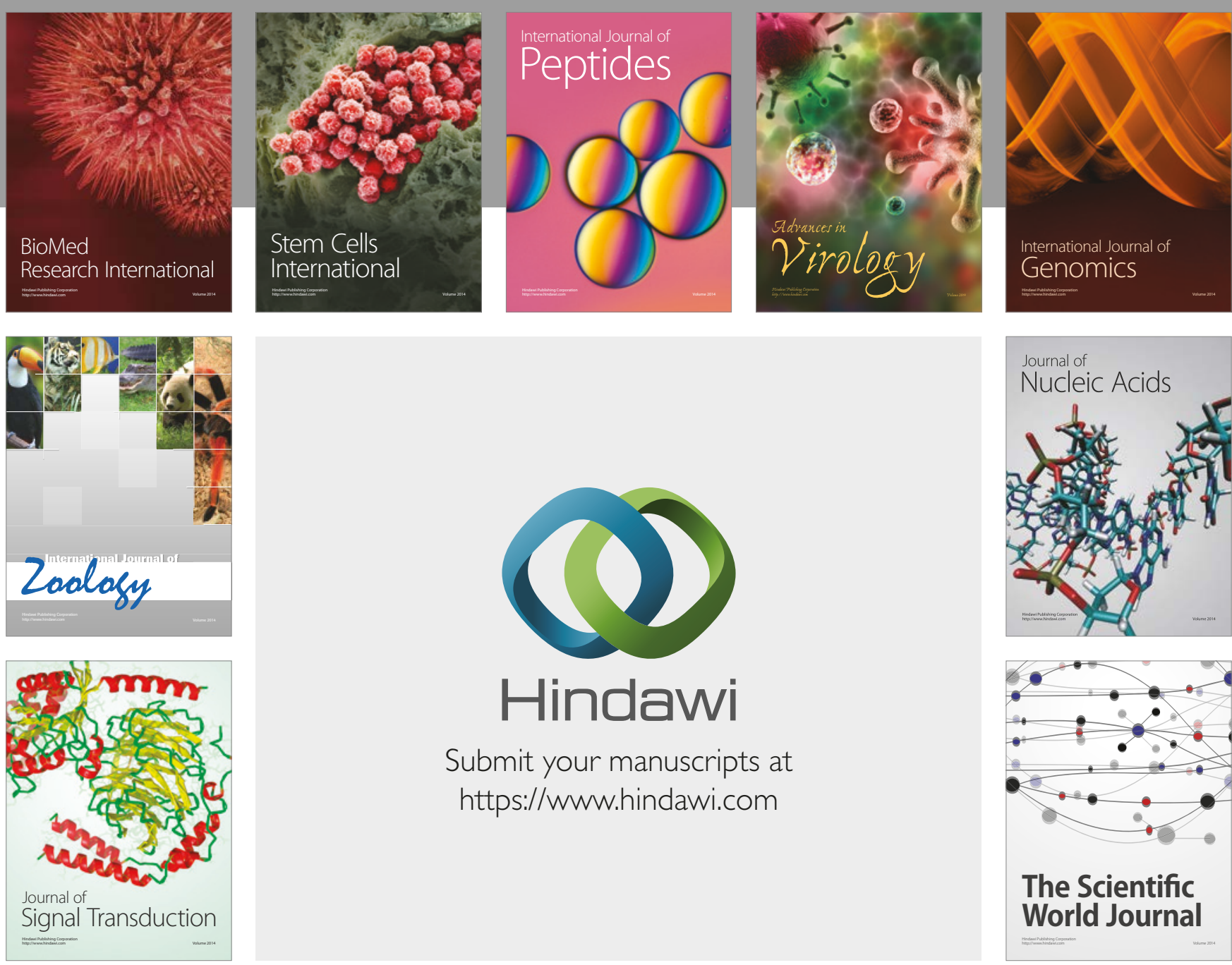

Submit your manuscripts at

https://www.hindawi.com
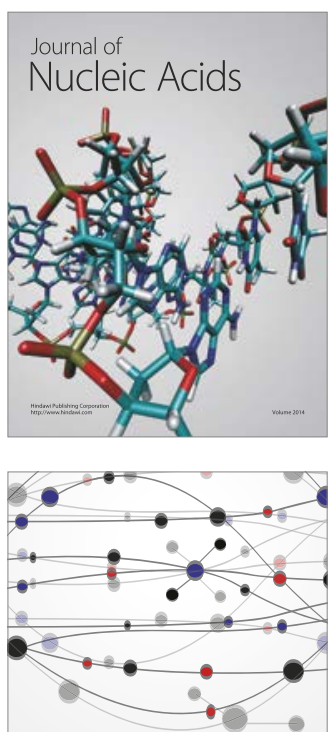

The Scientific World Journal

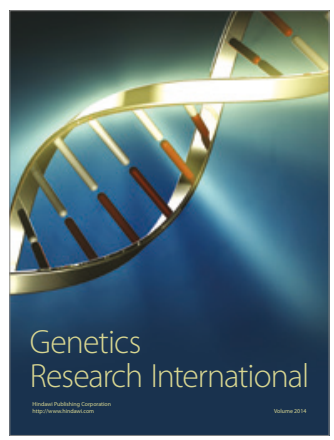

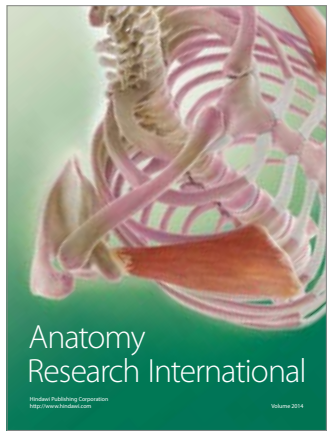

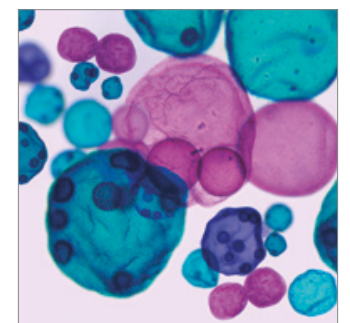

International Journal of Microbiology
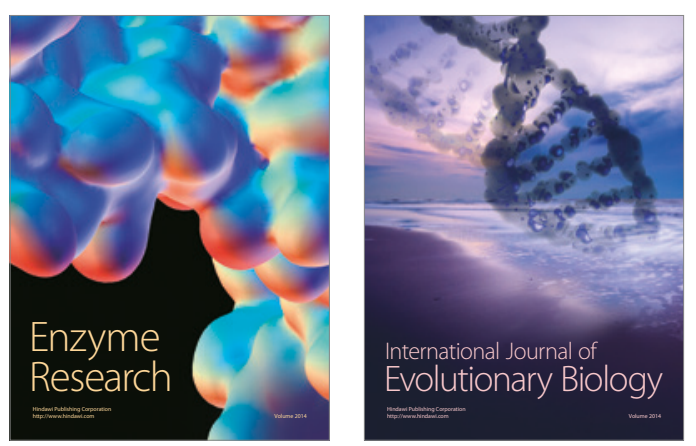
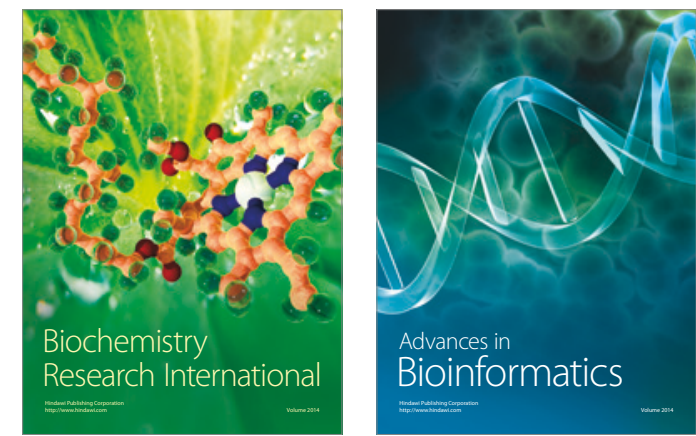

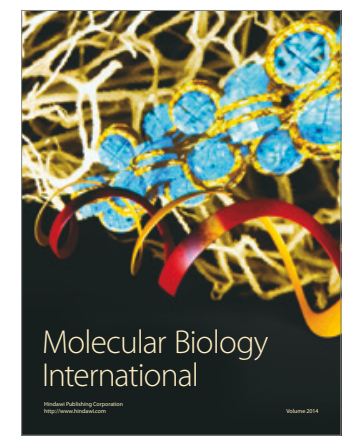

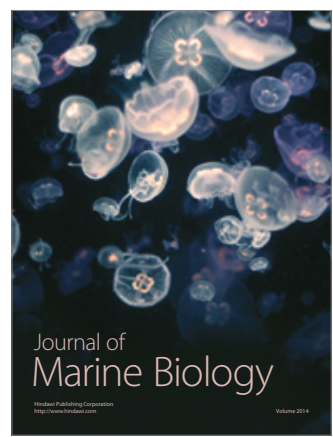

